Bangladesh J. Bot. 43(3): 309-314, 2014 (December)

\title{
JUTE (CORCHORUS OLITORIUS VAR. O-72) STEM LIGNIN: VARIATION IN CONTENT WITH AGE
}

\author{
AM Tanmoy, MA Alum, MS Islam ${ }^{1}$, T Farzana ${ }^{2}$ and H KhaN* \\ Molecular Biology Laboratory, Department of Biochemistry and Molecular Biology, \\ University of Dhaka, Dhaka-1000, Bangladesh
}

Key words: Jute, Lignin, Corchorus olitorius, Age vs lignin content

\begin{abstract}
Stem lignin content of a mature jute plant was found to be around $29 \%$ giving a deposition rate of $0.21 \%$ per day. The study was made on individual plants of different ages starting from five weeks when they were big enough to produce sufficient dry mass for lignin estimation to 16 weeks of age when a jute plant is ready for retting. An intense rate of increase (1.15\%) was found during the 7th week of growth, probably due to a rise in temperature. Present data and the average rate of increase of lignin production can be considered as a reference value for projects working on producing low-lignin - jute varieties.
\end{abstract}

\section{Introduction}

The bast fiber of two plants, namely Corchorus capsularis and C. olitorius (Sparrmanniaceae) are known as jute (Heywood et al. 2007). The fiber is collected after retting from the bast or outer region of the stem. This serves as a good source of different grades of pulp, since it has about $60 \%$ of cellulose. Became of its non-abrasive, light weight and biodegradable properties, the industrial applications of jute fiber have been augmented (Kuroda et al. 2002).

In Bangladesh, jute could be a suitable alternative not only as the raw material for paper pulping, but also for other wood-based industries. Chemically, the extracted jute fiber has about 59 - 61\% of cellulose while lignin content varies from 11.0 - 13.5\% (Islam and Sarkanen 1993, Giwa and Akwu 2007, Del Río et al. 2009). However, till now, not much data is available about the lignin content of either the jute stem or the whole plant from where the jute fiber originates.

Since lignin is the most recalcitrant component of the plant cell wall (Angelidaki and Ahring 2000), the higher the proportion of lignin the lower the bioavailability of the substrate (Richard 1996). Therefore, the downstream processing of jute would benefit from a reduced amount of this polymer. Researchers working to lower the lignin content of jute fibers by gene silencing will be benefited by knowledge of the amount of lignin a normal jute plant produces during different phases of its growth cycle. This will also help them to make comparison with their jute variety under development. Thus, to facilitate such initiatives, the present research was undertaken to study the lignin content of jute stem, focusing different growth stages of the plant.

\section{Materials and Methods}

Corchorus olitorius var. O-72 was used for the present study. Seeds were sown at two days intervals in two different plots of the Bangladesh Jute Research Institute (BJRI), and are named sample sets 1 and 2, respectively. Lignin estimations were made at one week intervals, starting from 5 weeks of age until the plants were ready for retting (approximately 16 weeks). Height of each plant recorded during the present study has been presented in Table 1.

*Author for correspondence: < haseena@du.ac.bd>. ${ }^{1}$ Breeding Division, Bangladesh Jute Research Institute (BJRI), Bangladesh. ${ }^{2}$ IFST, Bangladesh Council of Scientific and Industrial Research (BCSIR), Dhaka, Bangladesh. 
Klason lignin estimation method (Moore and Johnson 1967, Ehrman and Himmel 1994, Templeton and Ehrman 1995) was used to estimate the acid insoluble lignin (AIL). Lignin content of the jute fiber samples were measured to ascertain that the method was suitable for determining the amount of stem lignin in jute. To get the average lignin value of a plant, only the middle $16 \mathrm{~cm}$ section of the stem was used in this study. Two plants were taken per sample and estimated separately. All the samples were estimated twice to get an average value.

According to the estimation procedure, plant stems were first collected and cut off according to length. Then, they were dried at $105^{\circ} \mathrm{C}$ to get the dry weight (Ehrman 1994) and $\sim 0.5 \mathrm{~g}$ of sample was taken for estimation, denoted as $W_{1}$.

These dried samples were subjected to $72 \% \mathrm{H}_{2} \mathrm{SO}_{4}$ hydrolysis at room temperature, followed by $4 \% \mathrm{H}_{2} \mathrm{SO}_{4}$ hydrolysis at boiling temperature. The hydrolyzed solutions were then vacuumfiltered using filtering crucibles (glass crucibles with silica filter). After filtration, the crucibles with the residual content were heated at $105^{\circ} \mathrm{C}$ in a heating oven. Then, the weight of the crucibles with the dried residual content was taken, and denoted as $W_{2}$.

The next step was to heat the filtering crucibles with residual contents at $575 \pm 25^{\circ} \mathrm{C}$ in a muffle furnace (carried out at the Bangladesh Council of Scientific and Industrial Research, BCSIR). The crucibles were next cooled in a desiccator, weighed and the weight designated as $W_{3}$.

With these three different weights, the percentage of acid-insoluble lignin was calculated using the following formula (Templeton and Ehrman 1995):

$$
\text { Acid insoluble lignin }(\%)=\left\{\left(\mathrm{W}_{3}-\mathrm{W}_{2}\right) / \mathrm{W}_{1}\right\} \times 100
$$

The data were analyzed individually for two different sample data sets using MS excel. The correlation coefficient between the heights and lignin contents were estimated separately for both the sample sets. The square of correlation coefficient and slope of regression line were calculated individually for both the sample data sets.

\section{Results and Discussion}

Lignin content of jute fiber was estimated to verify our method. The estimated value was found to be 12.83 - 13.32\% (5 different samples with duplication). Since the value is within the previously reported range, (12.5 - 13.5\%) (Rahman 2010, Del Río et al. 2009) the method was considered appropriate for estimating jute lignin.

The estimated stem lignin contents of 5 - 16-week old jute plants are given in the Table 1 . Total increase in stem lignin content was found to be $16.11 \%$ (avg.) in 77 days. Highest increase, 8.04\% was found during the 7th week (43rd to 52nd days) of growth. During this period, the daily increase was $1.15 \%$ whereas the average increase in lignin content was $0.21 \%$ per day during the whole study period.

The correlation coefficient between the height and lignin content was found to be 0.89 and 0.91 , respectively for sample sets 1 and 2, indicating a strong correlation between these two variables (height and lignin content).

The square of correlation coefficient (correlation of determination, $\mathrm{R}^{2}$ ) for both the sample sets were found to be 0.72 and 0.71 , respectively suggesting that more than $70 \%$ variables in both data sets are in linear relationship. The slopes for linear correlations were found to be 0.17 and 0.19 implying a positive linear relationship. A t-test (two-tailed, unequal variance) was done to verify the similarity of two sample sets (Null hypothesis, $\mathrm{H}_{0}$ : means of both the sample set are equal at $5 \%$ confidence interval). A p value of 0.96 (accepts the $\mathrm{H}_{0}$ ) implies that the two sample sets were similar. 
As the second most abundant biopolymer on earth, lignin plays a critical role in the biogeochemical carbon cycle and affects the interaction between plants and other living organisms in a myriad of ways (Halpin et al. 2007). Huge variability is found in the lignin structure and content between different plant species (Halpin et al. 2007).

Table 1. Table for both the sample sets showing age, height, estimated and average lignin content of jute plant stem with the increment rate (increase per day).

\begin{tabular}{|c|c|c|c|c|c|c|c|}
\hline \multicolumn{3}{|c|}{ Sample set 01} & \multicolumn{3}{|c|}{ Sample set 02} & \multicolumn{2}{|c|}{ Average } \\
\hline $\begin{array}{l}\text { Age } \\
\text { (days) }\end{array}$ & $\begin{array}{c}\text { Height } \\
\text { (cm) }\end{array}$ & $\begin{array}{c}\text { Lignin } \\
\text { content (\%) }\end{array}$ & $\begin{array}{l}\text { Age } \\
\text { (days) }\end{array}$ & $\begin{array}{c}\text { Height } \\
(\mathrm{cm})\end{array}$ & $\begin{array}{c}\text { Lignin } \\
\text { content (\%) }\end{array}$ & $\begin{array}{c}\text { Lignin } \\
\text { content (\%) }\end{array}$ & $\begin{array}{c}\text { Increase per } \\
\text { day (\%) }\end{array}$ \\
\hline 37 & 48.6 & 13.42 & 35 & 64 & 13.61 & 13.515 & - \\
\hline 45 & 81 & 15.74 & 43 & 97 & 15.98 & 15.86 & 0.2931 \\
\hline 52 & 124 & 24.29 & 50 & 140 & 23.525 & 23.9075 & 1.1496 \\
\hline 58 & 149 & 25.07 & 56 & 142 & 24.68 & 24.875 & 0.1613 \\
\hline 65 & 180 & 26.325 & 63 & 190 & 26.895 & 26.61 & 0.2479 \\
\hline 73 & 198 & 25.96 & 71 & 214 & 27.32 & 26.64 & 0.0038 \\
\hline 79 & 205 & 26.61 & 77 & 221 & 27.865 & 27.2375 & 0.0996 \\
\hline 86 & 197 & 26.41 & 84 & 223 & 27.615 & 27.0125 & -0.032 \\
\hline 93 & 277 & 27.43 & 91 & 260 & 28.015 & 27.7225 & 0.1014 \\
\hline 100 & 305 & 28.66 & 98 & 242 & 28.34 & 28.5 & 0.1111 \\
\hline 107 & 314 & 29.43 & 105 & 300 & 28.88 & 29.155 & 0.0936 \\
\hline 114 & 279 & 29.62 & $*$ & $*$ & $*$ & $29.62 *$ & 0.1329 \\
\hline
\end{tabular}

*The plants for sample set 2 was unavailable, as they were subjected to retting on day 112.

In one study, lignin content of C. capsularis (JRC 212) fiber was found to be $21.36 \%$ (Sengupta and Palit 2004) whereas a fully grown jute plant stalk (or stick) is known to have between 24 - 25\% of Klason lignin (Islam and Sarkanen 1993, Roy et al. 1991, Bhattacharyya 1996). Before retting, Haque et al. (2001) found the lignin content of the fiber to be about $15 \%$ which eventually came down to $12-13 \%$ on completion of retting. However, this bast fibrous part is only $4.5-7.5 \%$ of whole plant or stem (non-dried) (Islam and Sarkanen 1993). It may also be noted that about $10 \%$ of the fiber (of a 120 day old plant) is lost during retting (Ahmed and Akhter 2001). Taking this into consideration together with the different values obtained for fiber and stick or stalk lignin, whole plant or stem lignin content could certainly be more than 25\%. Most measurements for lignin have been made for $C$. capsularis while little work has been done to know the content for either the stem or the stick of C. olitorius. Mosihuzzaman and co-workers found the stick lignin content of C. olitorius to be about 22\% (Mosihuzzaman et al. 1989). However, the sample collection method and plant growth condition of that study was not clear. In another study, lignin content of C. olitorius was found much higher than C. capsularis (Sinha 2004). The average fiber lignin content of $C$. olitorius was $17.06 \%$ whereas for C. capsularis it was $12.71 \%$ (Sinha 2004). It is therefore not unexpected that the whole plant lignin content will be much higher for $C$. olitorius than C. capsularis.

Pappas et al. (1998) had studied the lignin content in the bark, wood, and pith of four kenaf varieties and found values from $10.4-10.8,20.5-20.6$ and $14.9-15.3 \%$ of plant material, respectively. For flax, the lignin content in the bast fibre was found to vary between 1.5 and $4.2 \%$ of the dry cell wall residues as compared to values varying from 23.7 and $31.4 \%$ in the flax xylem tissue (Day et al. 2005). 
In our study, a mature jute (C. olitorius) plant stem (stick and bast fiber) was found to have on an average $28-29 \%$ of lignin (Table 1). For only the retted and dried bast fiber part, lignin was found to be $\sim 13 \%$ which is consistent with previous studies carried out in standard conditions (Palit and Meshram 2004). This ensured the accuracy of our measurements.

Our results also suggest that the lignin production rate in jute is not uniform. A huge increase in percentage was found during the $7^{\text {th }}$ week of its growth. In this particular week, total increase was found to be about $8 \%$ giving a rate of $1.15 \%$ per day, almost six-fold greater than the average increase $(0.21 \%)$ throughout the life cycle (Table 1$)$. This sudden increase could possibly have occurred due to an increase in temperature during this period (usually between May and June) as a positive correlation between lignin deposition and temperature has been previously reported (Ford et al. 1979, Villavicencio et al. 2007).

From the correlation coefficient between height and lignin content, it is evident that lignin deposition increases with height. The $\mathrm{R}^{2}$ value for both the sample sets $(0.72$ and 0.71$)$ indicates a good linear correlation between lignin production rate and time. Moreover, the slopes of the line for linear correlations, 0.17 and 0.19 suggest similarity between the samples sets in the rate of linear increment (Motulsky and Christopoulos 2004).

With such a rate of increase in lignin production, it is difficult to use jute in pulp and paper industry, since the main challenge in during the process is to remove lignin in a selective manner while preserving to the greatest possible extent the cellulose and hemi-celluloses (Santos 2013). High percentage of lignin interferes with chemical processes during the industrial processing, as it is embedded within a complex matrix with cellulose in the cell-wall (Li et al. 2008) called lignocellulose. This polymer also hinders the degradation of cell wall polysaccharides to simple sugars destined for fermentation to ethanol in case of biofuel production (Keating et al. 2006).

However, advances in plant transformation technology have facilitated researchers in manipulating lignin content and composition in a variety of plant species (Humphreys and Chapple 2002, Boudet et al. 2003). These efforts have resulted in transgenic plants with improved pulping efficiency or digestibility (Baucher et al. 2003, Halpin 2004, Li et al. 2008). Hybrids of brown midrib sorghum and Sudangrass are already in use in agriculture (Li et al. 2008). Moreover, there are reported transgenic varieties of different crops to have reduced lignin content like in alfalfa (Guo et al. 2001), tobacco (Ni et al. 1994, Sewalt et al. 1997), and maize (Piquemal et al. 2002).

Unfortunately, no such study has been undertaken for jute, in spite of its enormous potentiality. The present study is expected to help researchers working to produce low-lignin containing hybrid or GM-variety of jute. In the absence of any reference data it will take at least five months to confirm (time for growth till maturity and retting) if the lignin content has been successfully reduced in such studies. Early morphological changes (unpublished data) that occur due to the reduction in lignin content could also be of some indication, but not enough to confirm. Researchers will be able to use our data as a reference at an early stage (5 weeks of growth) to determine the success of their work. More than six trials a year will be achievable using these data while conducting even 3 trials per year is difficult without such knowledge. Possibilities of more trials would facilitate a researcher to try more combinations of cross-hybridization or gene silencing at a time.

\section{Acknowledgement}

The study was funded by BAS-USDA-PALS program in Bangladesh. 


\section{References}

Ahmed Z and Akhter F 2001. "Jute retting: An overview." Online J. Biol. Sci. 1(7): 685-688.

Angelidaki I and Ahring BK 2000. Methods for increasing the biogas potential from the recalcitrant organic matter contained in manure. Water Sci. \& Techn. 41(3): 189-194.

Baucher M, Halpin C, Petit-Conil M and Boerjan W 2003. Lignin: Genetic engineering and impact on pulping. Critical Reviews in Biochem. and Mol. Biol. 38(4): 305-350.

Bhattacharyya PC 1996. Wood Substitutes. Curr. Sci. 70(11): 950.

Boudet AM, Kajita S, Grima-Pettenati J and Goffner D 2003. Lignins and lignocellulosics: A better control of synthesis for new and improved uses. Trends in Plant Sci. 8(12): 576-581.

Day A, Ruel K, Neutelings G, Cronier D, David H, Hawkinns S and Chabbert B 2005 Lignification in the flax stem:evidence for an unusual lignin in bast fibers. Plant 222(2) 234-245

Del Río JC, Rencoret J, Marques G, Li J, Gellerstedt G, Jiménez-Barbero J, Martínez AT and Gutiérrez A 2009. Structural characterization of the lignin from jute (Corchorus capsularis) fibers. J. Agril. Food Chem. 57(21): 10271-10281.

Ehrman C and Himmel M 1994. Simultaneous saccharification and fermentation of pretreated biomass: improving mass balance closure. Biotech. Techniques 8(2): 99-104.

Ehrman T 1994. Standard method for determination of total solids in biomass. Laboratory Analytical Procedure (001).

Ford C, Morrison I and Wilson J 1979. Temperature effects on lignin, hemicellulose and cellulose in tropical and temperate grasses. Crop and Pasture Sci. 30(4): 621-633.

Giwa A and Akwu P 2007. Enhancement of colour fastness properties of direct dyed jute fabric by ammonium molybdate. Nigerian J. Sci. 41(2): 57-64.

Guo D, Chen F, Inoue K, Blount JW and Dixon RA 2001. Downregulation of caffeic acid 3-Omethyltransferase and caffeoyl CoA 3-O-methyltransferase in transgenic alfalfa: impacts on lignin structure and implications for the biosynthesis of G and S lignin. The Plant Cell 13(1): 73-88.

Halpin C 2004. Investigating and manipulating lignin biosynthesis in the postgenomic era. Adv.Bot. Res. 41: 63-106.

Halpin C, Thain SC, Tilston EL, Guiney E, Lapierre C and Hopkins DW 2007. Ecological impacts of trees with modified lignin. Tree Genetics \& Genomes 3(2): 101-110.

Haque MS, M. Asaduzzaman M, Akhter F and Ahmed Z. 2001. Retting of green jute ribbons (Corchorus capsularis var. CVL-1) with fungal culture. Online J. Biol. Sci. 1(11): 1012-1014.

Heywood VH, Brummitt RK, Culham A and Seberg O (2007). Flowering Plant Families of the World, Kew: Royal Botanical Gardens.

Humphreys JM and Chapple C 2002. Rewriting the lignin roadmap. Current Opinion in Plant Biol. 5(3): 224229.

Keating JD, Panganiban C and Mansfield SD 2006. Tolerance and adaptation of ethanologenic yeasts to lignocellulosic inhibitory compounds. Biotech. Bioengin. 93(6): 1196-1206.

Kuroda K, Izumi A, Mazumder BB, Ohtani Y and Sameshima K 2002. Characterization of kenaf (Hibiscus cannabinus) lignin by pyrolysis-gas chromatography-mass spectrometry in the presence of tetramethylammonium hydroxide. J. Analyti. Appl. Pyrolysis 64(2): 453-463.

Li X, Weng JK and Chapple C 2008. Improvement of biomass through lignin modification. The Plant Journal 54(4): 569-581.

Moore WE and Johnson DB 1967. Procedures for the chemical analysis of wood and wood products (as used at the US Forest Products Laboratory), Forest Products Laboratory, Forest Service, US Dept. of Agriculture.

Mosihuzzaman M, Quddus A, Nahar N and Theander O 1989. Comparative study of carbohydrayes in the two major species of jute (Corchorus capsularis and Corchorus olitorius). J. Sci. Food and Agril. 48: 305-310. 
Motulsky $\mathrm{H}$ and Christopoulos A 2004.Fitting models to biological data using linear and nonlinear regression: a practical guide to curve fitting. Oxford University Press, USA : 53-56.

Ni W, Paiva N and Dixon R 1994. Reduced lignin in transgenic plants containing a caffeic acid-Omethyltransferase antisense gene. Transgenic Research 3(2): 120-126.

Palit P and Meshram J 2004. Physiological characterization of a phenotypically distinct jute (Corchorus olitorius) genotype. Plant Genetic Resources 2(3): 175-180.

Pappas C. Tarantilis A and Polissiou M 1998. Determination of Kenaf (Hibiscus cannabinus L.) Lignin in crude plant material using diffuse reflectance infrared fourier transform spectroscopy. Applied Spectroscopy 52(11): 1399-1402

Piquemal J, Chamayou S, Nadaud I, Beckert M, Barrière Y, Mila I, Lapierre C, Rigau J, Puigdomenech P and Jauneau A 2002. Down-regulation of caffeic acid O-methyltransferase in maize revisited using a transgenic approach. Plant Physiology 130(4): 1675-1685.

Rahman MS 2010. Jute - A Versatile Natural Fibre. Cultivation, Extraction and Processing. In: Industrial Applications of Natural Fibres. John Wiley 135-161.

Richard T 1996. The effect of lignin on biodegradability. Cornell Composting.

Roy AK, Sen SK, Bag SC and Pandey SN 1991. Scanning electron microscopic study of jute stick treated with some pulping and bleaching agents. Holzforschung - Intl. J. Biol. Chem. Physics Technol. Wood 45(3): 209-214.

Santos RB, Peter WH, Hasan J and Chang H-M (2013) Wood based lignin recations important to the biorefineryand pulp and paper industry. Bio Resources 8(1) 1456-1477.

Sengupta G and Palit P2004. Characterization of a lignified secondary phloem fibre-deficient mutant of jute (Corchorus capsularis). Ann. Bot. 93(2): 211-220.

Sewalt VJH, Ni W, Blount JW, Jung HG, Masoud SA, Howles PA, Lamb C and Dixon RA 1997. Reduced lignin content and altered lignin composition in transgenic tobacco down-regulated in expression of Lphenylalanine ammonia-lyase or cinnamate 4-hydroxylase. Plant Physiol. 115(1): 41-50.

Sinha MK 2004. Jute quality breeding by reducing lignin content. In "New directions for a diverse planet" edited by Fischer RA. Proceedings for the 4th International Crop Science Congress, Brisbane, Australia, 26 September - 1 October 2004.

Templeton D and Ehrman T 1995. Determination of acid-insoluble lignin in biomass. Laboratory Analytical Procedure (003).

Villavicencio LE, Blankenship SM, Yencho GC, Thomas JF and Raper CD 2007. Temperature effect on Skin adhesion, cell wall enzyme activity, lignin content, anthocyanins, growth parameters and periderm histochemistry of sweetpotato. J. Amer. Soc. Hort. Sci. 132(5): 729-738.

(Manuscript received on 23 March, 2013; revised on 17 September, 2014) 